\title{
症例報告
}

\section{食道アカラシアによる頸肩部痛が 内視鏡的食道筋層切開術で改善した 1 症例}

\author{
木本文子 ${ }^{* 1}$ 別府幸岐 ${ }^{* 1}$ 境 徹也 ${ }^{* 2}$ \\ 深野 拓 ${ }^{* 1}$ 南ひとみ*3
}

[要旨］症例は 43歳女性で, 両頸部から肩にかけての痛みを主訴に麻酔科を受診した．頸肩部の 筋緊張が強いため, 筋筋膜性疼痛症候群を疑い, 各種神経ブロックを行ったが, 効果は一時的であ った. また, 初診時より, 喉頭の絞扼感および嚥下困難が認められたが, 軽度であったため経過観 察としていた. 初診時から5年後, 頸肩部痛に加え, 嚥下困難および食後頻回の嘔吐を生ずるよ うになった. 嬹下造影検査で食道拡張, 造影剤の食道停滞の所見があったため, 食道アカラシアと 診断された. 内視鏡的食道筋層切開術後, 嚥下障害は劇的に改善し, 頸肩部痛も消失した. この診 療経過から, 頸肩部痛が食道アカラシアの関連症状であると考えられた.

キーワード : 食道アカラシア, 頸肩部痛, 内視鏡的食道筋層切開術, 関連痛, 筋筋膜性疼痛症候群

\section{はじめに}

食道アカラシアとは，下部食道括約筋の弛緩不全 のため, 食物や唾液が食道に滞留してしまう結果, 食道の拡張と蠕動運動障害をきたす疾患である。一 般的な症状・徵候としては, 胸部のつかえ感, 胸痛, 嶼下障害，食道内停留物の逆流に伴う咳，誤嬩性肺 炎などがある。今回，われわれは食道アカラシアが 原因と考えられた頸肩部痛の 1 症例を経験したので 報告する。

\section{I 症 例}

43 歳, 女性。身長 $152 \mathrm{~cm}$, 体重 $49 \mathrm{~kg}$. 両頸部か ら肩にかけての痛みを主訴に麻酔科を受診した。既 往歴には特記すべき事項はなかった。両頸肩部の強 い筋緊張以外は血液検査, X 線検査で異常はなかっ
た。筋筋膜性疼痛症候群を疑い，トリガーポイント 注射，頸神経叢ブロック，星状神経節ブロックを施 行したが，効果は一時的であった。アセトアミノフ エン，葛根湯，チザニジン，セレコキシブ，プレガ バリンを内服し，両頸肩部痛は日常生活に支障がな い程度にコントロールされていた。初診時より喉頭 の絞扼感や嚥下困難, 食後の嘔吐などの症状があつ たが，軽度で増悪が認められず，5年間当科で経過 を観察していた。初診から 5 年後, 両頸肩部痛に著 変はなかったが, 嚥下困難や食後の嘔吐が増強した。 近医内科での上部消化管内視鏡検査では異常なく, ラベプラゾールナトリウムのみが処方されていた. しかし, 症状は改善せず経口摂取不能となり, 体重 も減少したため, 再度当科を受診した。当院耳鼻科 での燕下造影検査で，食道拡張，造影剂の食道停滞 の所見があり, 当院消化器内科紹介となった。食道
${ }^{* 1}$ 国家公務員共済組合連合会 佐世保共済病院麻酔科

${ }^{* 2}$ 国家公務員共済組合連合会

佐世保共済病院ペインクリニック科

*3 長崎大学病院消化器内科
受付日 2018. 4. 18.

受理日(採択日) 2018. 6.13.
著者連絡先 木本文子

干 857-8575 長崎県佐世保市島地町 10-17 国家公務員共済組合連合会 佐世保共済病院麻酔科 
A

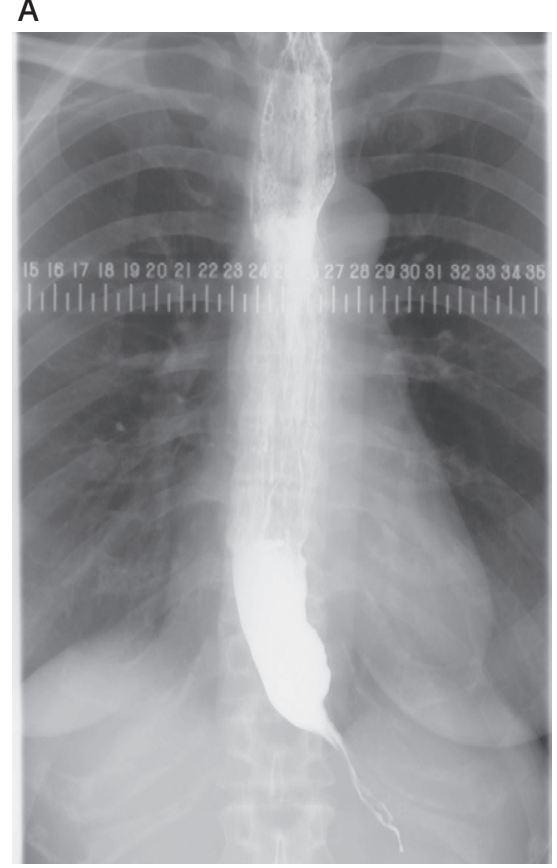

B

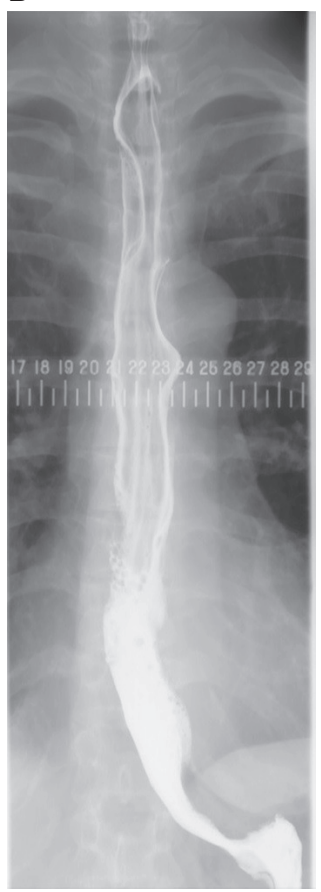

図1 内視鏡的食道筋層切開術前後の食道造影検査

内視鏡的筋層切開術前に認められた, 拡張した食道と造影剂 の貯留, 食道胃接合部のなだらかな狭窄 $(\mathrm{A})$ が, 術後には消 失している (B).

造影検査では, バリウムの胃への排出遅延, 食道胃 接合部のなだらかな狭窄 (bird beak sign)が見られた (図1A)。上部消化管内視鏡検査では, 食道内腔の 拡張と液体の貯留が見られた(図2A)。胸部CTでは, 著明な食道拡張および夜面形成を認めた (図 $2 \mathrm{~B})$. 以 上の所見より，食道アカラシアと診断された。まず はカルシウム拮抗薬による内服治療が行われたが, 血圧低下による気分不良が強く, 内服が継続できな かった。 その後, 経口内視鏡的食道筋層切開術 $($ peroral endoscopic myotomy : POEM)が施行された. 施行後の食道造影検査では, 胃食道狭窄部の狭窄が 解除され，バリウムの通過は良好となった(図1B). POEM施行後に当科を受診した際には嚥下障害は 劇的に改善しており, 両頸肩部痛も消失していた。 頸肩部痛が食道アカラシアの関連症状であった可能 性が高いと考えられた。当科処方分の内服薬を徐々
に中止していったが，中止後も再発することなく経 過している。

\section{II 考察}

食道アカラシアとは，下部食道括約部の弛緩不全 と食道体部の蠕動運動の障害を認める原因不明の食 道運動機能障害と定義され，本邦における年間発症 率は $0.4 \sim 1.1 / 10$ 万人とされる稀な疾患である ${ }^{1)}$. 下 部食道の通過障害に加えて, 食道体部に同期性収縮 を含む異常運動, 食道体部の拡張, 壁肥厚などが見 られる。最も典型的な自覚症状は固形物・流動物の 燕下困難で, その他に口腔内逆流, 胸痛, 体重減少, 夜間咳嗽などがある ${ }^{2)}$. 胸痛は約半数の患者で見ら れ, 通過障害の自覚症状に数年以上も先行して胸痛 のみを呈する症例もある ${ }^{3)}$.

本症例では疼痛部位は胸部ではなく頸肩部で，ま 

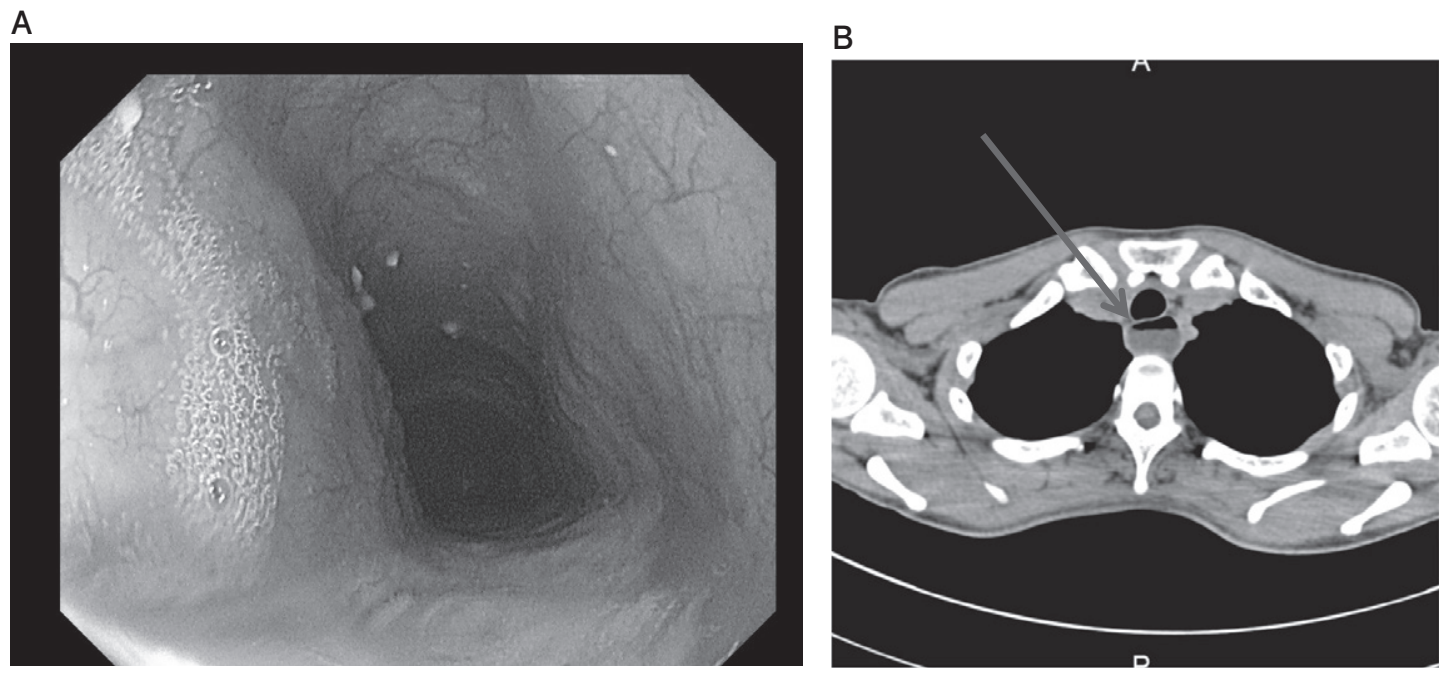

図2上部消化管内視鏡検査所見と胸部 CT 所見

A：上部消化管内視鏡検査では，食道内腔の拡張と液体の貯留を認める.

B：胸部 CTでは, 食道の拡張および液面形成を認める (矢印).

た通過障害の自覚症状が顕在化するまでに 5 年経過 していた。通過障害の自覚症状がそしく診断に時間 を要する症例は多く報告されており, 喘鳴や慢性咳 嗽などの呼吸器症状が主で，喘息として加療されて いた症例も散見される ${ }^{4), 5)}$.また, 心身症や摂食障害, 機能性消化管疾患との鑑別を要した症例など，精神 科, 心療内科領域からの報告も少なくない ${ }^{6) ~ 8)}$. 消 化器症状があっても, 症状が典型的でない場合や, 食道の拡張度が低い場合はアカラシアの診断は難し く, 症状出現からアカラシアの診断までの期間(病 悩期間) は平均 $2.4 \sim 10.9$ 年と報告されており, 診断 までに長時間を要することが多い9 ${ }^{9)}$.

アカラシアの診断には，上部消化管内視鏡検査, 食道造影，食道内圧検査が有用である。上部消化管 内視鏡検査では, 食道内腔の拡張, 食物残椬や液体 の貯留などが見られる ${ }^{1)}$.上部消化管内視鏡検査は 初期検査として施行されることが多いが，初期の段 階では異常所見にそしく，アカラシアを疑わなけれ ば見過ごされる可能性も高い。本症例においても， 当院受診前の上部消化管内視鏡検査で異常所見は指 摘されなかった。食道造影検査では, 食道の拡張・
蛇行，食物残椬やバリウムの食道内停滞，食道胃接 合部の平滑な狭小像(bird beak sign)などが見られ る。食道造影検査は簡便で侵襲も少なく, 初期でも 有用である。本症例でも，近医消化器内科で異常な しとの診断であったため, 咽頭部での鱟下障害を疑 い，耳鼻科での與下造影検査とそれに続いて施行さ れた食道造影検査が診断のきっかけであった。與下 造影検査を施行しなかった場合には，さらに診断が 遅れた可能性もあった。

食道アカラシアの治療法には, 内服治療，内視鏡 的バルーン拡張術, ボッリヌス毒素局注療法, 腹腔鏡 下 Heller 手術, 経口内視鏡的食道筋層切開術 $(\mathrm{POEM})$ などがある。POEMとは，2008年に開発された食 道アカラシアに対する新たな低侵襲内視鏡治療法で ある。経口内視鏡を用いて経粘膜下層的に食道内輪 筋切開を行い, 下部食道括約部の狭窄を解放する ${ }^{3)}$. 本症例でも, 全身麻酔下にPOEMが施行され, 嘖 下障害は劇的に改善し，頸肩部痛も消失した。

本症例では主症状が両頸肩部痛であり，一般的な 食道アカラシアでの胸痛とは異なっていた。この原 因は不明であるが，食道の関連痛であった可能性は 
ある. 関連痛とは, 内藏での発症刺激の部位とは離 れた皮膚や皮下に出現する痛みである。これは，内 臓神経が脊髄に刺激を入力すると，同じレベルに入 力している体性神経に影響を与えることで生じる. 上部食道の脊髄分節の高さはC4-5であり, 放散部 位は前頸部となる ${ }^{10)}$ 。食道がんの関連痛では, 食物 通過時の内圧上昇に伴う痛みや，椎体周囲組織浸潤 に伴う頸肩部の痛みが特徵的とされている ${ }^{11}$. 本症 例では, 頸肩部に強い筋緊張があり, 反射性筋収縮 による関連痛と推測された。アカラシアの下部食道 狭窄により，食道内腔圧が上昇し，C4-5分節の筋 群に筋収縮の刺激が伝達され，収縮による筋虚血か ら侵害刺激物質が放出され, 疼痛を引き起こしたの ではないかと考えられた。

本症例では, 両頸肩部には筋肉の硬結と圧痛点( 卜 リガーポイント)が存在し，トリガーポイント注射 が一時的にせよ効果があった点などから，筋筋膜性 疼痛症候群としても矛盾はしない. 食道アカラシア の症状や，ストレスによる筋緊張も加わり, 骨格筋 の中の筋性のトリガーポイントに起因する局所的な 痛 $の$ 疾患である ${ }^{12}$ 筋筋膜性疼痛症候群の発症に至 つた可能性がある. POEM施行後は, 一次的な原 因である食道アカラシアが改善したため, 二次的に 発生した筋筋膜性疼痛症候群も改善したと考えられ た.

\section{結語}

今回われわれは食道アカラシアが原因と考えられ た頸肩部痛の 1 症例を経験した。本症例では, 食道 アカラシアで一般的な症状が当初は多くなかったた め，その診断に苦慮し時間を要した。
本症例の報告にあたり，患者本人からの許諾と所 属施設の承認を得ている。

本稿の要旨は日本臨床麻酔学会第 37 回大会 $(2017$ 年，東京)において発表した。

\section{参考文献}

1）柏木秀幸, 小澤壯治, 小村伸朗ほか：食道アカラシア 取扱い規約 (第4 版)。日本食道学会編。金原出版, 東京, 2012, 3-6

2) Boeckxstaens GE, Zaninotto G, Richter JE : Achalasia. Lanset $383: 83-93,2014$

3）南ひとみ, 萩原久美, 田㴊真惟子ほか：食道アカラシ アに対する内視鏡治療：POEM. 消化器内視鏡 29： 281-286, 2017

4）平井邦朗, 小田成人, 五藤哲ほか：治療反応性にそし い喘鳴と慢性咳嗽の原因が食道アカラシアであった 1 例. 日本呼吸器学会誌 $5: 279-283,2016$

5）三神美子，煙石真弓，平井康太ほか：気管支喘息とし て加療されていた 7 歳女児の食道アカラシアの 1 例。 日 本小児呼吸器学会雑誌 $26: 177-183,2015$

6）村田真彦, 奥見裕邦, 高橋史彦ほか：摂食障害や機能 性消化管疾患との鑑別を要した食道アカラシアの1例. 日本心療内科学会誌 $19: 33-38,2015$

7）城井義隆, 吉益晴夫, 湯田初ほか：嚥下困難の主訴に 対して, 身体症状症打よび関連症群が疑われたが，精 查により食道アカラシアと判明した一例。精神科治療 学 $30: 1367-1370,2015$

8）大賀由紀，永田良隆，河野祥二ほか：嘔吐と体重減少 を認め心身症が疑われた食道アカラシアの 13 歳女览例. 小児科臨床 $66: 2269-2275,2013$

9）橋本卓典, 遠藤美紀子, 倉田貴規ほか：診断に 5 年を要 した食道アカラシアの一例. 日赤検查 $46: 31-35,2013$

10）萩原秀紀, 房本英之：上部消化管由来の痛みの特徵一 診断と治療法の概略一. 痛みと臨床 $1: 23-30,2001$

11）冨安志郎, 澄川耕二：がんの痛みと関連痛. ペインク リニック $26: 543-553,2005$

12) Borg-Stein J, Laccarino MA : Myofascial pain syndrome treatment. Phys Med Rehabil Clin N Am 25 : 357-374 


\title{
A Case of Esophageal Achalasia Presented with Neck and Shoulder Pain : Successful Treatment with Per-oral Endoscopic Myotomy
}

\author{
Ayako KIMOTO*1, Yuki BEPPU ${ }^{* 1}$, Tetsuya SAKAI*2, \\ Taku FUKANO*1, Hitomi MINAMI*3 \\ ${ }^{* 1}$ Department of Anesthesiology, Sasebo Kyosai Hospital \\ ${ }^{* 2}$ Department of Pain Clinic, Sasebo Kyosai Hospital \\ ${ }^{* 3}$ Department of Gastroenterology and Hepatology, Nagasaki University Hospital
}

A 43-year-old female suffered from bilateral neck and shoulder pain. She visited our clinic 5 years ago. We diagnosed her as having myofascial pain syndrome because of high-tension muscle at her bilateral neck and shoulder. However, the efficacy of some neuraxial block therapy was temporary. After that, dysphagia and vomiting which existed at first visit became worse, and esophagography revealed a narrowing of the lower esophagus. We diagnosed her as having esophageal achalasia. After undergoing per-oral endoscopic myotomy, her dysphagia completely improved and her neck and shoulder pain disappeared. We therefore assumed that her neck and shoulder pain may be associated with esophageal achalasia.

Key Words : Esophageal achalasia, Neck and shoulder pain, Per-oral endoscopic myotomy, Referred pain, Myofascial pain syndrome

The Journal of Japan Society for Clinical Anesthesia Vol.38 No.5, 2018 